\title{
Surface Fuel Sampling Strategies: Linking Fuel Measurements and Fire Effects
}

\author{
Dirac Twidwell, ${ }^{1}$ Samuel D. Fublendorf, ${ }^{2}$ David M. Engle, ${ }^{3}$ and Charles A. Taylor, Jr. ${ }^{4}$
}

Authors are ${ }^{1}$ Research Assistant, Texas A\&M University, Department of Ecosystem Science and Management, College Station, TX 77843, USA; ${ }^{2}$ Professor, Oklahoma State University, Department of Natural Resource Ecology and Management, Stillwater, OK 74078, USA; ${ }^{3}$ Professor and Director of Water Research and Extension Center, Oklahoma State University, Department of Natural Resource Ecology and Management, OK 74078, USA; and and ${ }^{4}$ Regent Fellow and Professor, Texas A\&M University, Texas A\&M Agrilife Research Center, Sonora, TX 76950, USA.

\begin{abstract}
We assessed the effectiveness of different sampling strategies in linking fine fuel load and crown scorch of ashe (Juniperus ashei) and redberry juniper (J. pinchotii) for prescribed fires conducted in wet and dry periods of the growing season on the Edwards Plateau, Texas, USA. Our aim was to determine if spatial and temporal variation in crown scorch was best predicted by estimates of fuel load sampled with spatially explicit, multiscale sampling strategies or with traditional, simple random sampling of fuel load. We found that multiscale sampling of fuel load underneath and adjacent to juniper crowns was more effective than simple random sampling in predicting crown scorch for the 14 fires conducted in the wet period and the five conducted in the dry period. The type of sampling strategy employed was critical in relating fuel load to crown scorch during the wet period. Percent crown volume scorched ranged from $0 \%$ to $100 \%$ in these conditions. In contrast, the type of sampling strategy was less important in the dry period when crown scorch was $>90 \%$ for all juniper trees. We use these findings to illustrate how a multiscale sampling design can increase prediction power, thereby improving our ability to provide resource professionals with critical values to target in management. Using such a strategy in this study revealed that fine fuel loading of $2670 \mathrm{~kg} \cdot \mathrm{ha}^{-1}$ were needed to scorch juniper trees $100 \%$ for the conditions present in the wet period, whereas only $1280 \mathrm{~kg} \cdot \mathrm{ha}^{-1}$ were needed in the dry period. To provide managers with this type of information, we suggest that researchers shift from simple, random sampling of fuels to alternate sampling designs where randomization is maintained in the designation of treatments or selection of observations (i.e., individual juniper trees) but where fuel is systematically sampled at the location of the observation of interest.
\end{abstract}

\section{Resumen}

Evaluamos la efectividad de diferentes estrategias de muestreo relacionándolas con la disponibilidad de combustible fino y el combustible quemado de la corona de los juníperos cenizo (Juniperus Ashei) y rojo (Juniperus pinchotii), por fuegos controlados efectuados durante periodos húmedos y secos de la época de crecimiento en las Edwards Plateau de Texas, USA. Nuestro objetivo era determinar si la variación espacial y temporal en el combustible quemado de la corona podía predecirse mejor por medio de las estimaciones de muestreo de disponibilidad de combustible con estrategias de muestreo explícito espacialmente a multi-escala o con el tradicional muestreo aleatorio simple de disponibilidad de combustible. Encontramos que el muestreo a nivel de multi-escala debajo y en áreas cerca a la corona del junípero fue más efectivo que el simple muestreo aleatorio para predecir el combustible quemado de la corona en los 14 fuegos realizados en el periodo húmedo y los cinco fuegos realizados en el periodo seco. El tipo de estrategia de muestreo que se empleó fue crucial para relacionar la disponibilidad de combustible y el combustible quemado de la corona durante el periodo húmedo. El volumen porcentual de la corona quemada varió de 0 a $100 \%$ bajo esas condiciones. En contraste, la estrategia de muestreo fue menos importante durante el período seco, cuando el combustible quemado de la corona sobrepasaba el $90 \%$ para todos los juníperos. Utilizamos estos resultados para ilustrar cómo un diseño de muestreo a multi-escala puede incrementar el poder de predicción, mejorando así nuestra habilidad de proporcionar recursos profesionales con valores críticos para objetivos de manejo. Utilizando tal estrategia en este estudio, concluimos que una disponibilidad de combustible fino de $2670 \mathrm{~kg} \cdot \mathrm{ha}^{-1}$ es necesaria para quemar $100 \%$ los árboles de junípero bajo las condiciones presentes durante el periodo húmedo, mientras que solo $1280 \mathrm{~kg} \cdot \mathrm{ha}^{-1}$ se necesitan durante el periodo seco. Para darles a los manejadores esta información, sugerimos a los investigadores cambiar del simple muestreo aleatorio de combustible al diseño alterno de muestreo, donde la aleatoriedad se mantiene en el diseño de los tratamientos o en la selección de las observaciones (como los arboles de junípero), pero cuando el combustible es muestreado sistemáticamente en el lugar de interés de observación.

Key Words: crown scorch, fuel load, functional scale, Juniperus, prescribed fire, random sampling

Research was supported by US Dept of Agriculture Forest Service, Texas A\&M Agrilife Research Center, and Oklahoma Agricultural Experiment Station.

Correspondence: Dirac Twidwell, Texas A\&M University, Dept of Ecosystem Science and Management, 2126 TAMU, Animal Industries Building, College Station, TX 77843, USA. Email: dirac@tamu.edu

Manuscript received 8 May 2008; manuscript accepted 23 February 2009.

\section{INTRODUCTION}

A primary focus of research in fire ecology is to identify links among fuels, fire intensity, and fire effects. Numerous studies have investigated how fire intensity influences immediate fire effects (Albini 1976; Rothermel and Deeming 1980; Williams et 
al. 1998, 1999), and, more recently, fine-scale variation in fire intensity (i.e., differences in the heat produced by the fire over small distances, areas, or time) has been attributed directly to the presence and distribution of species in the postfire community (Thaxton and Platt 2006). However, limited research has identified how prefire heterogeneity in fuels influences localized variation in fire intensity and effects within a fire.

Juniper (Juniperus spp.) invasion into grassland results in localized variation in fine fuel load that may contribute to heterogeneous effects within a fire. Fine fuel is reduced beneath juniper crowns as the size and number of invaders increase (Engle et al. 1987; Smith and Stubbendieck 1990; Gehring and Bragg 1992) but varies depending on the amount of light penetration, allelopathic effects, and the abundance and distribution of shed juniper foliage (Engle et al. 1987). This, coupled with the spatial variation in fine fuel load that is inherent in many grassland systems, leads to complex surface fuels at fine scales. Such fine-scale heterogeneity in fuel load alters fire intensity and effects in low-intensity fires (Thaxton and Platt 2006), but traditional field sampling techniques (e.g., simple random) may not effectively detect and relate variation in surface fuel loads to fire intensity and fire effects.

The purpose of this study was to evaluate how effectively a simple random and two multiscale sampling strategies predict variation in fire intensity and crown scorch on juniper trees burned in wet and dry periods of the growing season. Although fire intensity was not measured directly in this study, crown scorch was assumed to be a proxy to fire intensity, an approach applied frequently in analyses of fire effects on conifer (Coniferus spp.) and juniper spp. (Van Wagner 1973; Rothermel and Deeming 1980; Engle and Stritzke 1995; Williams et al. 1998). Spatial variation in fire intensity was defined here as local differences in crown scorch that occurred within an experimental fire treatment and temporal variation in fire intensity as intraseasonal differences in crown scorch driven by wet and dry periods of the growing season. Sampling strategies were used to test the following hypotheses: 1) spatial variation in fuel load and fire intensity drive variation in crown scorch within burn treatments, and 2) this variation will be explained best by a sampling strategy that measures fuel load at a scale relative to individual juniper crowns.

\section{METHODS}

\section{Study Area}

This investigation was conducted at the Texas A\&M University Agrilife Research Center located near Sonora, Texas, on the Edwards Plateau (Hatch et al. 1990). Annual precipitation is $670 \mathrm{~mm}$ (90-yr mean) with high interannual variability. The site experiences bimodal distribution of precipitation in the spring and fall with frequent prolonged summer drought. Herbaceous vegetation, composed primarily of mid- and short grasses, dominates the fuel, but continuity is disrupted by bare ground, rock outcrops, and woody encroachment of ashe juniper (Juniperus ashei), redberry juniper (Juniperus pinchotii), live oak (Quercus virginiana), and Vasey shin oak (Quercus Pungens; Fuhlendorf and Smeins 1998). Soils formed from Tarrant stony clays, classified as Lithic Haplustolls, are generally $15-30 \mathrm{~cm}$ deep and include frequent limestone outcrops (Wiedenfeld and McAndrew 1968; Fuhlendorf and Smeins 1996). Current juniper canopy cover and total woody canopy cover is approximately $20 \%$ and $40 \%$, respectively (Smeins et al. 1997). Herbivory treatments were applied at light rates in 40-ha experimental units since 1998 as part of a longterm experimental design. Herbivory was excluded from experimental units for the duration of this experiment.

\section{Experimental Design}

Two fire treatments, wet-period versus dry-period fires, were applied to five $50-\mathrm{m}$ transects in six of the long-term experimental units. Transects were established and assigned treatments randomly in each unit except that 1) transects were oriented in the direction of the prevailing wind (e.g., northsouth) so that all transects burned as headfires, 2) transects were greater than $100 \mathrm{~m}$ apart to enable each transect to be lit independently, and 3) all transects were assigned the same fire treatment within each experimental unit to remain consistent with the long-term design of the site (see Fuhlendorf and Smeins 1997). Although the experiment was designed and sampled with equal replicates between treatments, environmental constraints precluded similar burn conditions on all 15 transects in each treatment, resulting in 14 burned transects for the wet period and five for the dry period.

\section{Prefire Sampling}

Individual juniper trees were sampled along each $50-\mathrm{m}$ transect using the line-intercept method (Floyd and Anderson 1987). The location and aerial coverage was measured for each juniper crown that overlapped the transect. Juniper trees had to be $\geq 1.5 \mathrm{~m}$ tall and overlap with at least $1.5 \mathrm{~m}$ of the transect to be included in this analysis. Tree height and crown diameter were measured to the nearest $0.25 \mathrm{~m}$.

Fine fuel load was estimated systematically in $1000.5 \times 0.5$ $\mathrm{m}$ quadrats along each transect. Destructive sampling techniques that remove fine fuel were avoided to prevent humaninduced alteration of fire behavior along transects. Instead, four fuel load classes (FLCs) were developed to estimate fine fuel load, similar to how vegetation cover is estimated as classes (Daubenmire 1959). With this technique, the amount of fuel in each quadrat was assessed visually and classified into an FLC of $0,1,2$, or 3 , with 0 and 3 representing the lowest and highest FLCs, respectively.

To determine if this technique was accurate and repeatable, FLCs were calibrated by randomly collecting fuel load samples in $500.5 \times 0.5 \mathrm{~m}$ quadrats for each fire treatment. Fine fuel load was assessed visually in each quadrat and assigned to one of the four FLCs. The total live and dead fine fuel in each quadrat was clipped and collected, dried for $48 \mathrm{~h}$ at $70^{\circ} \mathrm{C}$, and weighed to determine the actual dry weight of the fine fuel in each quadrat. The dry weight of each sample was then compared to the FLC predicted in the field. Regression analysis was used to determine the strength of the relationship $\left(r^{2}\right)$ between FLC and fuel load. Fuel load class means were tested for significant differences using one-way analysis of variance.

\section{Fire Application}

Transects were burned in similar weather conditions in order to identify differences that were a result of the wet- and dry-period 
fire treatments and not confounded by variation in environmental factors between treatments. Temperature $\left({ }^{\circ} \mathrm{C}\right)$, relative humidity $(\%)$, and wind speed $\left(\mathrm{km} \cdot \mathrm{h}^{-1}\right)$ were monitored prior to and during implementation of the wet-period fire treatments. Weather conditions from wet-period fires were later targeted when fire treatments were implemented in the dry period of the growing season. Transects were burned in the dry period only after obtaining a weather forecast with similar estimates for temperature, relative humidity, and wind speed.

Each transect was burned with a $10-\mathrm{m}$ wide head fire. A person with a drip torch lit a continuous fire front from a point $5 \mathrm{~m}$ west of the transect origin to a point $5 \mathrm{~m}$ east. Transects were burned for wet- and dry-period treatments on 13-14 July 2004 and 2 August 2005, respectively.

\section{Sampling During the Fire}

Fuel moisture and weather characteristics were measured at the time of ignition of each plot. Fine fuel moisture was quantified by clipping the total live and dead fine fuel material to ground level in five random $0.25-\mathrm{m}^{2}$ quadrats adjacent to each transect. Quadrats were not located within $5 \mathrm{~m}$ of each transect to prevent alteration of fire behavior via fuel removal. Fuel moisture samples $(n=95)$ were weighed immediately on clipping, oven dried at $70^{\circ} \mathrm{C}$ for $48 \mathrm{~h}$, and then reweighed to calculate fuel moisture on a dry-weight basis. Juniper foliar moisture content was measured for two juniper trees per transect by collecting foliage from the terminal $0.2 \mathrm{~m}$ of branches at a height of $1.0-1.5 \mathrm{~m}$ above the soil surface. Temperature $\left({ }^{\circ} \mathrm{C}\right)$, relative humidity $(\%)$, and wind speed $\left(\mathrm{km} \cdot \mathrm{h}^{-1}\right)$ were measured $30 \mathrm{~m}$ downwind of the transect origin at a height of $1.5 \mathrm{~m}$ using a Kestrel 4000 (Nielson-Kellerman, Boothwyn, PA), a weather data logger, from the time the fire was ignited to the time the fire either reached the end of the transect or ceased to spread within the transect.

\section{Postfire Sampling}

Aboveground fire effects were quantified 2 wk following each fire by visually assessing percent crown volume scorched to the nearest $10 \%$ for all juniper trees that intersected each transect. Percent crown volume scorched was used instead of scorch height because it is a more accurate estimate of crown scorch (Peterson 1985), and scorch height does not describe scorch effects when numerous trees are scorched completely.

\section{Comparison of Fuel Sampling Strategies}

Measures of fine fuel load along the transect were used to develop three distinct sampling strategies to determine which strategy best predicted crown scorch within each fire treatment. The difference between sampling strategies was how quadrats were combined to generate a fuel load sample. Quadrats along the transect were aggregated to coalesce fuel load values 1) at random, 2) at arbitrary scales of measurement about each individual tree, and 3) at functional scales of measurement about each individual tree (Table 1). Aggregate fuel load values were used to correlate juniper crown scorch with fire intensity. Fine fuel load was used as an independent variable for correlating juniper crown scorch with fire intensity since fine fuel consumption was $100 \%$ in all cases where fine fuel was consumed in the experimental burns.
A simple random sampling strategy was established to evaluate fuel sampling techniques that are typically applied in field studies of fire effects (Table 1). In a simple random sampling strategy, fuel loads are measured at random locations, and the results are extrapolated to represent the mean fuel load of the entire area (e.g., Bidwell and Engle 1992; Engle and Stritzke 1995; Briggs et al. 2002; Streeks et al. 2005). Monte Carlo simulation was used to randomly select 10 quadrats along the transect. Fuel load values within those quadrats were averaged to obtain the mean fuel load for each transect. Next, the mean fuel load for that transect was coupled with the juniper tree located on that same transect. This process was repeated for all juniper trees within each fire treatment (e.g., seven trees for wet period, 10 trees for dry period) to calculate the correlation $(r)$ between the randomly derived mean fuel load and juniper crown scorch for each fire treatment. Simulations were then repeated, thereby coupling 10 new quadrats with each juniper tree to calculate an additional correlation $(r)$ between the randomly derived mean fuel load and juniper crown scorch. Simulations were repeated 1500 times. Variability among correlations was evaluated to determine the repeatability of a simple random sampling design.

The second sampling strategy used in this study related the juniper crown to the fuel load that occurred at arbitrarily selected spatial scales about the midpoint of the crown (Table 1). An arbitrarily based multiscale sampling strategy is frequently applied when studies aim to quantify and link process-pattern relationships within heterogeneous environments (O’Neill et al. 1989, 1991). Arbitrary spatial scales were chosen by aggregating fuel load attributes of individual quadrats located at equidistant intervals from the canopy midpoint of each juniper tree. Aggregation of fuel load values began at a distance of $1.0 \mathrm{~m}$ and increased at $0.5-\mathrm{m}$ intervals until reaching a final scale of $15.0 \mathrm{~m}$. Variation $\left(r^{2}\right)$ in crown scorch explained by the mean fuel load at each arbitrary scale was then calculated to determine the scale(s) that best predicted crown scorch in wet- and dry-period fire treatments.

The final strategy used in this study identified functional scales between fuel load and the juniper crown (Table 1). Functional scales were selected by considering 1 ) the extent to which fuel load is influenced by the juniper overstory crown, 2) how to choose a scale when tree sizes varied considerably as in this study, and 3) the potential for crown scorch to be influenced by fire intensity as a function of the fine fuel load occurring underneath and near juniper trees. We therefore chose four functional scales that depict quadrats corresponding to the intercept of the juniper crown along the transect and at lag distances of $1 \mathrm{~m}, 2 \mathrm{~m}$, and $3 \mathrm{~m}$ outside the crown intercept. Subsequently, functional scales were variable scales driven by differences in the size of each individual tree. These data were used to evaluate whether the functional sampling strategy to choosing a scale could improve juniper crown scorch prediction in comparison to multiple scales selected arbitrarily. Significant differences in the predictive ability of the functional and arbitrary sampling strategies were tested using a two-way analysis of variance with the Bonferroni correction (Benjamini and Hochberg 1995).

To determine which sampling strategy was most reliable in relating fuel load to crown scorch, correlation coefficients $(r)$ produced with the simulation of the simple random sampling 
Table 1. Description of how fuel loads were related to juniper crowns using random and multiscale sampling techniques. Fuel loads were mapped at $0.5-\mathrm{m}$ intervals along a $50-\mathrm{m}$ transect. Fuel loads were related to juniper crown scorch at various resolutions by averaging $0.5-\mathrm{m}$ plots at random or at the specified spatial scale.

\begin{tabular}{|c|c|c|c|}
\hline Sampling technique & Resolution (m) & No. of $0.5-\mathrm{m}$ plots & Scale dependence between fuel load and juniper crown \\
\hline Simple random & 50.0 & 10 & None; samples collected at random \\
\hline \multirow[t]{8}{*}{ Arbitrary scales } & 1.0 & 2 & Samples summed at the crown midpoint \\
\hline & 1.5 & 3 & Samples summed in equidistant directions from crown midpoint \\
\hline & 2.0 & 4 & Samples summed in equidistant directions from crown midpoint \\
\hline & - & - & - \\
\hline & - & - & - \\
\hline & - & - & - \\
\hline & 14.5 & 29 & - \\
\hline & 15.0 & 30 & - \\
\hline \multirow[t]{4}{*}{ Functional scales } & $1.5-6.0$ & Varies & Samples summed at crown intercept and vary with crown size \\
\hline & $1.5-7.0$ & Varies & $\begin{array}{l}\text { Samples summed at crown intercept plus } 1 \mathrm{~m} \text { from edge of crown and } \\
\text { vary with crown size }\end{array}$ \\
\hline & $1.5-8.0$ & Varies & $\begin{array}{l}\text { Samples summed at crown intercept plus } 2 \mathrm{~m} \text { from edge of crown and } \\
\text { vary with crown size }\end{array}$ \\
\hline & $1.5-9.0$ & Varies & $\begin{array}{l}\text { Samples summed at crown intercept plus } 3 \mathrm{~m} \text { from edge of crown and } \\
\text { vary with crown size }\end{array}$ \\
\hline
\end{tabular}

strategy were compared to those produced by arbitrary and functional sampling strategies at the scale that best predicted the relationship. Strategies were compared by identifying the number of times the random strategy produced a correlation coefficient that exceeded that of the multiscale strategies. A probability level of 0.05 was established for this test, meaning that the correlation coefficient of the arbitrary and functional strategies had to exceed $95 \%$ of the correlation coefficients produced by the simple randomized strategy.

\section{RESULTS}

\section{Fuel Load Classes}

Fuel loading (class mean \pm SE) of $107 \pm 12,978 \pm 36$, $2203 \pm 53$, and $4062 \pm 102 \mathrm{~kg} \cdot \mathrm{ha}^{-1}$ represented FLCs of 0 , 1,2 , and 3 , respectively. One-way analysis of variance revealed class means to be significantly different $(P<0.001$ for all class means). The strength of the relationship $\left(r^{2}\right)$ between FLC and fuel load was $0.90(P<0.0001)$.

\section{Fire Prescriptions}

Temperatures were not significantly different between fire treatments. Minimum and maximum values were 28.5 and $38.5^{\circ} \mathrm{C}$ in the wet period, respectively, compared to 33.5 and $38.4^{\circ} \mathrm{C}$ in the dry period, respectively. Relative humidity was higher in the dry period $(P<0.01)$ with lower and upper limits of $22.9-26.1 \%$ in the dry period and $12.4-29.1 \%$ in the wet period. Wind speed, juniper foliage moisture, and fine fuel moisture were lower in the dry period $(P<0.01,0.05$, and 0.0001 , respectively). Wind speed ranges were $1.0-3.1 \mathrm{~km} \cdot \mathrm{h}^{-1}$ in the dry period compared to $3.2-11.6 \mathrm{~km} \cdot \mathrm{h}^{-1}$ in the wet period. Juniper foliage moisture content ranged from 42.0$80.9 \%$ in the dry period versus $70.0-128.0 \%$ in the wet period. Fine fuel moisture limits were $3.0-8.5 \%$ in the dry period as opposed to $12.7-29.3 \%$ in the wet period.

\section{Sampling Comparisons}

The functional sampling strategy explained the greatest amount of variation in crown scorch during the wet period at the scale of the crown intercept $\left(r^{2}=0.81, P<0.05\right)$. The ability for other functional scales to explain variation in crown scorch decreased at increasing distances from the crown (Fig. 1). An arbitrary sampling strategy produced similar results. Crown scorch was explained more effectively by finer scales of resolution than those scales that included fuel load measurements further away from juniper crowns (Fig. 2). The greatest amount of variation explained by the arbitrary sampling strategy was $76 \%$ at spatial scales of $5.5 \mathrm{~m}$ and $6.0 \mathrm{~m}$. Alternatively, fuel load was a poor predictor of crown scorch during the dry period, regardless of spatial scale or sampling technique (Figs. 1 and 2). Crown scorch was independent of the amount and distribution of fine fuel load in these conditions. All juniper trees were scorched $>90 \%$. Arbitrary and functional strategies were significantly superior to simple random sampling in both fire treatments $(P<0.001$ and 0.05 for functional strategy in wet and dry treatments, respectively; $P<0.05$ for arbitrary strategy in wet and dry treatments). Correlations $(r)$ between crown scorch and fuel loads sampled with a simple random strategy ranged from $<0.01$ to 0.93 in wet-period fires and from $<0.01$ to 0.65 in the dry period.

The critical amount of fine fuel needed to completely scorch juniper trees was derived using the functional sampling strategy for the fuel and weather conditions present during this study. In the wet-period fire treatment, all juniper crowns were scorched $100 \%$ when fine fuel load was $\geq 2670 \mathrm{~kg} \cdot \mathrm{ha}^{-1}$, whereas only $1280 \mathrm{~kg} \cdot \mathrm{ha}^{-1}$ were needed in the dry period to cause the same effect (Fig. 1A).

\section{DISCUSSION}

Sampling within the immediate vicinity of juniper crowns using functional and arbitrary sampling strategies was more effective 
A.

B.

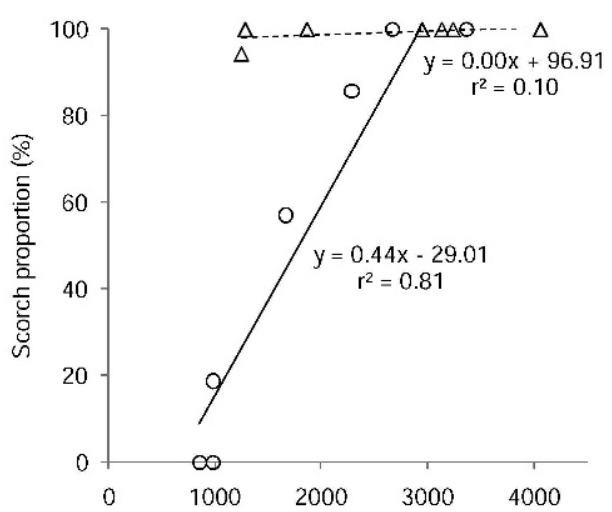

C.
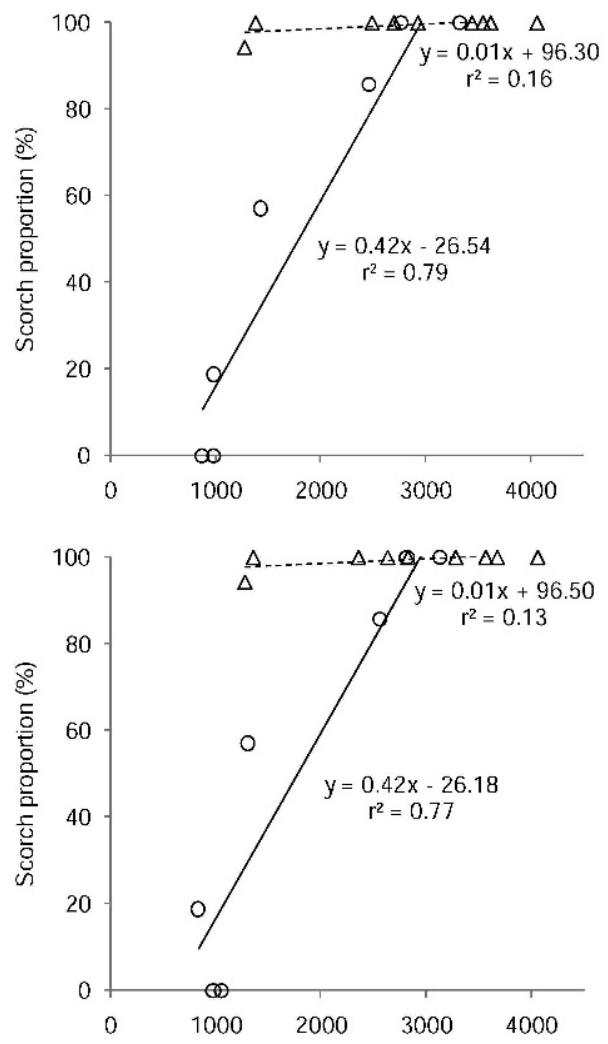

D.

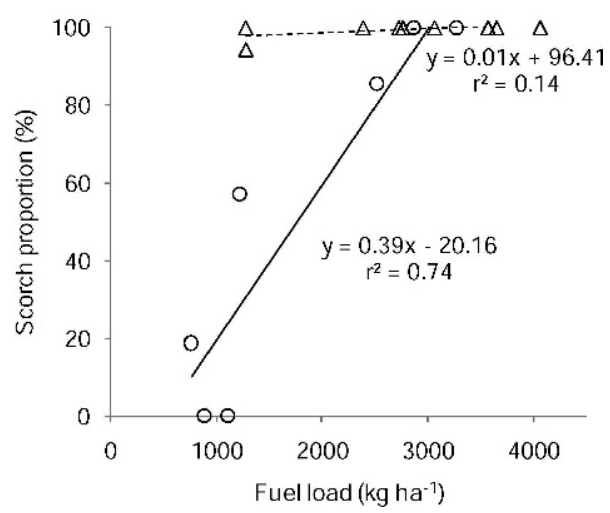

Figure 1. Relationship between crown scorch and the mean fuel load sampled about the juniper crown with a functional sampling strategy during wet-period (shown as circle with solid line) and dry-period (shown as triangle with dashed line) fire treatments. Functional scales corresponding to $\mathbf{A}$, the crown intercept and at lag distances of $\mathbf{B}, 1.0 \mathrm{~m}$, C, $2.0 \mathrm{~m}$, and $\mathbf{D}, 3.0 \mathrm{~m}$ from the crown intercept are shown.
A.

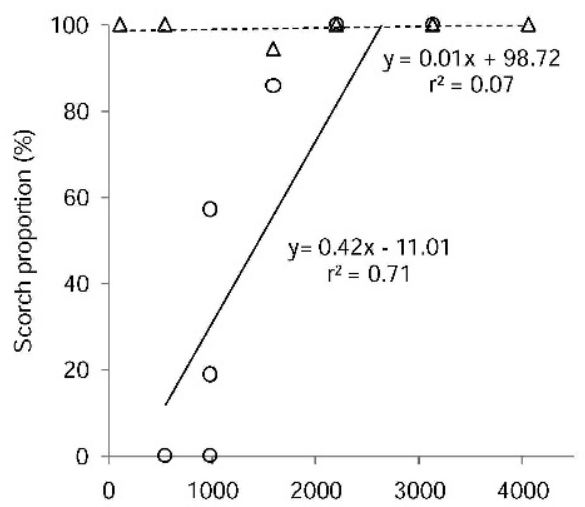

B.

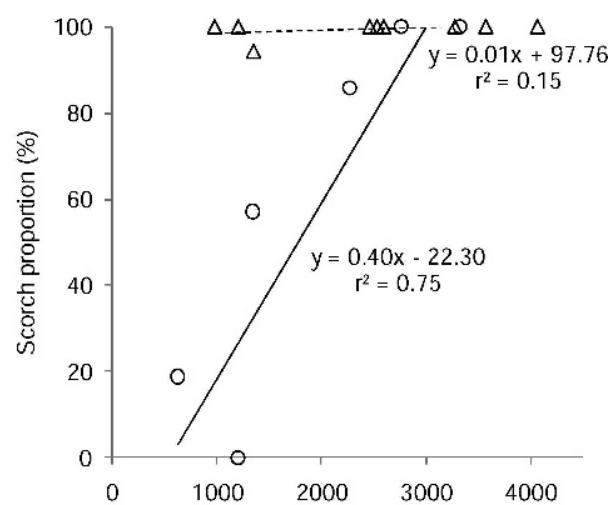

C.

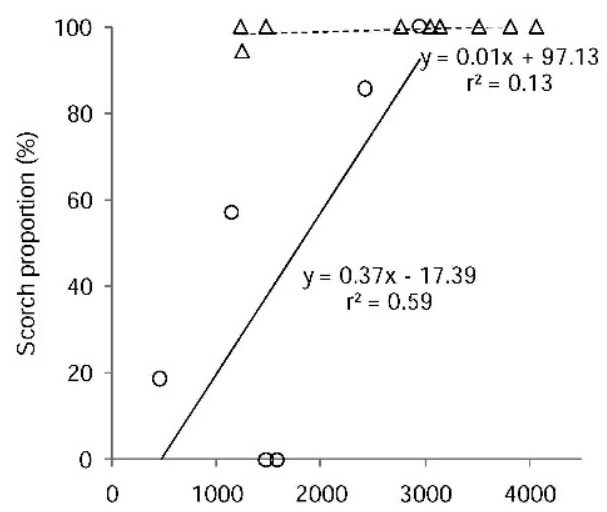

D.

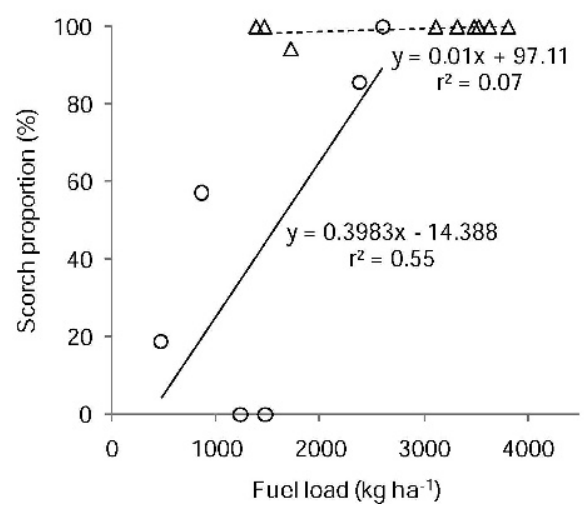

Figure 2. Relationship between crown scorch and the mean fuel load sampled about the juniper crown with an arbitrary sampling strategy during wet-period (shown as circle with solid line) and dry-period (shown as triangle with dashed line) fire treatments. Selected for illustration were arbitrary scales of $\mathbf{A}, 1.0 \mathrm{~m}, \mathbf{B}, 5.0 \mathrm{~m}, \mathbf{C}, 10.0 \mathrm{~m}$, and $\mathbf{D}$, $15.0 \mathrm{~m}$. 
A.

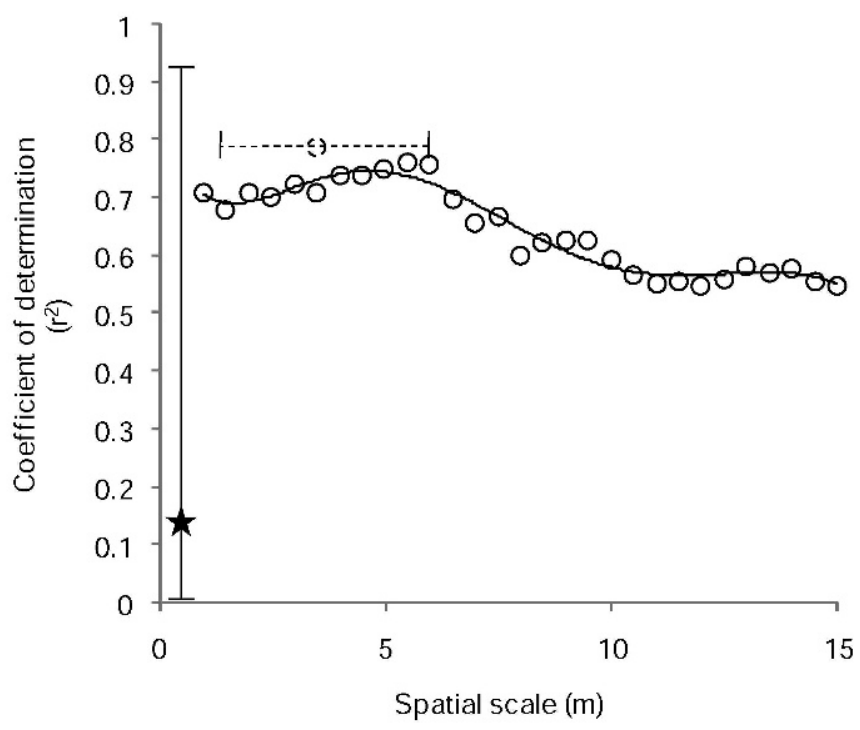

B.

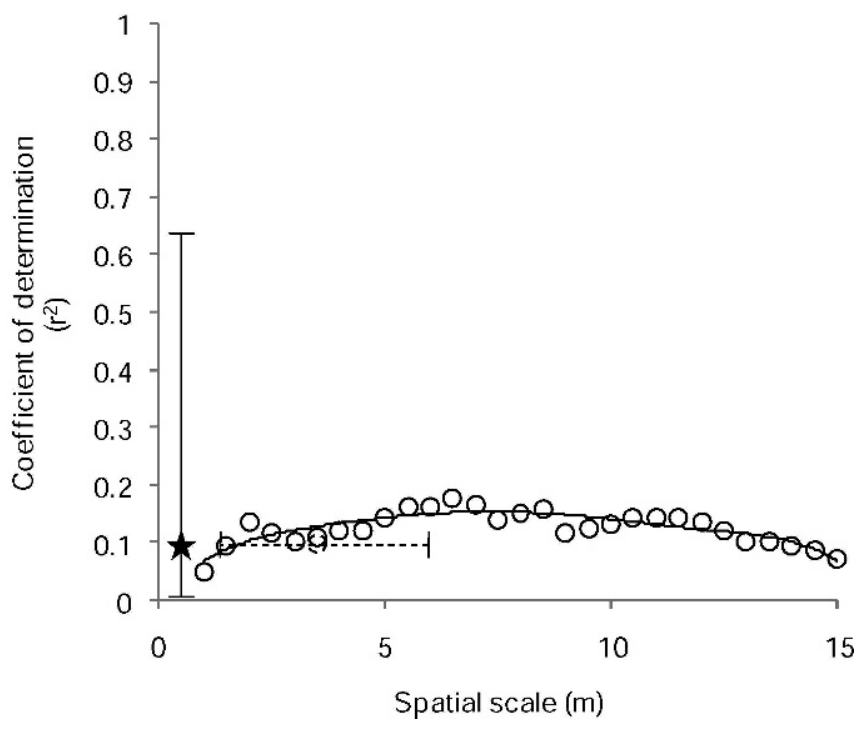

Figure 3. Illustration comparing the amount of variation in crown scorch explained by the mean fuel load sampled using simple random (vertical bar), arbitrary (solid line), and functional (dashed line) sampling strategies for fires conducted in $\mathbf{A}$, wet-period fires and $\mathbf{B}$, dry-period fires. Only the functional scale corresponding to the crown intercept is shown here. Note that the star and surrounding bar represent the average and range, respectively, in correlations between crown scorch and random fuel load samples selected using Monte Carlo simulation.

than simple random sampling in predicting crown scorch for both wet- and dry-period fire treatments. Such findings demonstrate that a transition in field sampling is needed to identify causal relationships linking fuels, fire behavior, and fire effects in heterogeneous systems. Field methods need to be consistent and produce repeatable results to make valid interstudy comparisons, something traditional, simple random sampling techniques were unable to produce in this heterogeneous environment (Fig. 3). The vast range of correlations produced in both wet- and dry-period fire treatments when using such a strategy demonstrates that two studies could have identical fuel characteristics, fire behavior, and fire effects yet still yield dramatically different results. In search of more consistent results, studies in other ecological subdisciplines have employed a multiscale approach (O'Neill et al. 1989, 1991; Turner 1989; Wiens 1989) to overcome potential problems that arise when analyzing process-pattern relationships in heterogeneous environments. We used such an approach to design a multiscale assessment of arbitrarily and functionally defined relationships between fuel load and crown scorch as the fire environment changes from mild (e.g., wet period) to extreme (e.g., dry period). The type of sampling strategy employed was less important in the dry period, when low moisture contents of fine fuels and juniper foliage were more dominant drivers than fuel load, resulting in high levels of crown scorch for all fuel loads ranging from 1000 $\mathrm{kg} \cdot \mathrm{ha}^{-1}$ to $4200 \mathrm{~kg} \cdot \mathrm{ha}^{-1}$ (Figs. 1 and 2). Conversely, sampling strategy was critically important in relating scorch to fuel load in wet-period fires for a similar range of fuel load values (Figs. 1 and 2).

Although the use of a simple random sampling strategy has been a staple of fire effects-related research, transitioning to an alternate strategy that is more effective in the presence of heterogeneity should be relatively straightforward. The primary problem with simple random sampling in heterogeneous systems is that samples are collected arbitrarily at locations independent from the observation of interest. Alternate experimental designs and sampling approaches, such as stratified random sampling (Gillison and Brewer 1985; Fortin et al. 1989) or nonrandom spatially autocorrelated designs (Fortin et al. 1989; Legendre 1993; Dale 1999; Fortin et al. 2002; Fortin and Dale 2005), maintain randomness by randomly selecting individual observations (e.g., individual trees) and then sampling the factors that drive the effect (e.g., fuel, fire intensity) at that location. Since fuel load under the juniper crown was the most appropriate scale of measurement for the conditions in this study (Fig. 3), one can envision a more intricate design that nests a sampling grid about each juniper tree such that pattern in fuel load can be derived at multiple spatial scales and then related to juniper crown scorch. Such a design may prove useful in accounting for fine-scale variation in other fuel characteristics that may interact with variation in fine fuel load to alter fire intensity and effects at local scales. Spatial variation in fuel moisture, for example, may increase variation in effects within a fire (Peet and Allard 1993; Drewa et al. 2002; Knapp and Keeley 2006). Additionally, higher wind speeds, variable topography, and localized differences in surface fuel types, among other factors, may be important drivers of spatial variation in fire behavior and effects. Sampling designs that can account for these sources of variation at multiple scales have the potential to identify the relative importance of fine fuel load versus other factors in driving spatial variation in fire intensity and fire effects.

\section{MANAGEMENT IMPLICATIONS}

Quantifying spatial and temporal drivers of fire effects can improve applications of research in management (Williams et al. 1994). For example, a critical amount of fine fuel is currently identified as the primary driver of scorch and 
mortality of juniper trees in rangelands (Fuhlendorf et al. 1996; Briggs et al. 2002, 2005). In this study, however, all juniper trees were completely scorched in the dry-period fire treatment, regardless of the amount and distribution of fine fuel load (Fig. 1A). Multiple pathways therefore exist for resource professionals attempting to use fire to manage and restore rangelands. While this study was not established to provide an exhaustive depiction of mechanisms of crown scorch, it does illustrate how researchers can provide managers with precise information on the factors required to completely scorch juniper crowns. For fires conducted in the fuel and weather conditions of the wet-period treatment, managers should target a fine fuel load value of $2670 \mathrm{~kg} \cdot \mathrm{ha}^{-1}$ that occurs beneath juniper trees (Fig. 1A). In contrast, managers need only 1280 $\mathrm{kg} \cdot \mathrm{ha}^{-1}$ when fires are conducted in the fuel and weather conditions present during the dry-period treatment (Fig. 1A). With this information, managers will be able to target specific values from an array of environmental drivers, ultimately leading to more successful management in rangeland systems.

\section{ACKNOWLEDGEMENTS}

We wish to acknowledge the Agrilife Research Station Fire Crew, especially Nick Garza, Terry Brooks, Erika Campbell, Jack Turney, Colin Rosser, and Robert Moen. We also thank Justin D. Derner and the contributions of multiple anonymous reviewers.

\section{LITERATURE CITED}

ALBINI, F. A. 1976. Estimating wildfire behavior and effects. Ogden, UT, USA: US Dept of Agriculture, Forest Service, General Technical Report, INT-30. 92 p.

BenJaminI, Y., AND Y. HochBerg. 1995. Controlling the false discovery rate: a practical and powerful approach to multiple testing. Journal of the Royal Statistical Society. Series B (Methodological) 57:289-300.

Bidwell, T. G., And D. M. Engle. 1992. Relationship of fire behavior to tallgrass prairie herbage production. Journal of Range Management 45:579-583.

BRIGGS, J. M., G. A. Hoch, AND L. C. Johnson. 2002. Assessing the rate, mechanisms and consequences of the conversion of tallgrass prairie to Juniperus virginiana forest. Ecosystems 5:578-586.

Dale, M. R. T. 1999. Spatial pattern analysis in plant ecology. Cambridge, UK: Cambridge University Press. $340 \mathrm{p}$.

Daubenmire, R. F. 1959. Canopy coverage method of vegetation analysis. Northwest Science 33:43-64.

Drewa, P. B., W. J. Platt, and E. B. Moser. 2002. Fire effects on resprouting of shrubs in headwaters of southeastern longleaf pine savannas. Ecology 83:755-767.

Engle, D. M., and J. F. Stritzke. 1995. Fire behavior and fire effects on eastern redcedar in hardwood leaf-litter fires. International Journal of Wildland Fire 5:135-141.

Engle, D. M., J. F. Stritzke, and P. L. Claypool. 1987. Herbage standing crop around eastern redcedar trees. Journal of Range Management 40:237-239.

Floyd, D. A., And J. E. Anderson. 1987. A comparison of three methods for estimating plant cover. Journal of Ecology 75:221-228.

Fortin, M. J., ANd M. R. T. Dale. 2005. Spatial analysis: a guide for ecologists. Cambridge, UK: Cambridge University Press. $382 \mathrm{p}$.

Fortin, M. J., M. R. T. Dale, and J. ver Hoef. 2002. Spatial analysis in ecology. Encyclopedia of Environmetrics 4:2051-2058.

Fortin, M. J., P. Drapeau, and P. Legendre. 1989. Spatial autocorrelation and sampling design in plant ecology. Plant Ecology 83:209-222.

Funlendorf, S. D., and F. E. Smeins. 1996. Spatial scale influence on long-term temporal patterns of a semi-arid grassland. Landscape Ecology 11:107-113.
Funlendorf, S. D., And F. E. Smeins. 1997. Long-term importance of grazing, fire, and weather patterns on Edwards Plateau vegetation change. In: C. A. Taylor [ED.]. Proceedings of Juniper Symposium. College Station, TX, USA: Texas Agricultural Experiment Station Technical Report 97-1. p. 7.19-7.20.

Funlendorf, S. D., and F. E. Smeins. 1998. The influence of soil depth on plant species response to grazing within a semiarid savanna. Plant Ecology 138:89-96.

Funlendorf, S. D., F. E. Smeins, and W. E. Grant. 1996. Simulation of a fire-sensitive ecological threshold: a case study of Ashe juniper on the Edwards Plateau of Texas, USA. Ecological Modelling 90:245-255.

GeHRING, J. L., AND T. B. BragG. 1992. Changes in prairie vegetation under eastern red cedar (Juniperus virginiana L.) in an eastern Nebraska bluestem prairie. American Midland Naturalist 28:209-217.

Gillison, A. N., And K. R. Brewer. 1985. The use of gradient directed transects or gradsects in natural resource surveys. Journal of Environmental Management 20:103-127.

Hatch, S. L., K. N. Ghadi, And L. E. Brown. 1990. Checklist of the vascular plants of Texas. College Station, TX, USA: Texas Agricultural Experiment Station MP1655. $158 \mathrm{p}$.

Knapp, E. E., and J. E. Keeley. 2006. Heterogeneity in fire severity within early season and late season prescribed burns in a mixed-conifer forest. International Journal of Wildland Fire 15:37-45.

Legendre, P. 1993. Spatial autocorrelation: trouble or new paradigm? Ecology 74:1659-1673.

O'Neill, R. V., A. R. Johnson, And A. W. KIng. 1989. A hierarchical framework for the analysis of scale. Landscape Ecology 3:193-205.

O'Neill, R. V., S. J. Turner, V. I. Uluinan, D. P. Coffin, T. Cook, W. Conley, J. Brunt, J. M. Thomas, M. R. Conley, and J. Gosz. 1991. Multiple landscape scales: an intersite comparison. Landscape Ecology 5:137-144.

Peet, R. K., and D. J. Allard. 1993. Longleaf pine vegetation of the southern Atlantic and eastern Gulf Coast regions: a preliminary classification. Proceedings of the Tall Timbers Fire Ecology Conference 18:45-81.

Peterson, D. L. 1985. Crown scorch volume and scorch height: estimates of postfire tree condition. Canadian Journal of Forest Research 15:596-598.

Rothermel, R. C., AND J. E. Deeming. 1980. Measuring and interpreting fire behavior for correlation with fire effects. Washington, DC, USA: US Dept of Agriculture, Forest Service, General Technical Report, INT-93. 3 p.

Smeins, F. E., S. D. Funlendorf, and C. A. TAylor. 1997. Environmental and land use changes: a long-term perspective. In: C. A. Taylor [ED.]. Proceedings of Juniper Symposium. College Station, TX, USA: Texas Agricultural Experiment Station Technical Report 97-1. p. 1.3-1.21.

Smith, S. D., And J. StubBendieck. 1990. Production of tallgrass prairie herbs below eastern red cedar. Prairie Naturalist 22:13-18.

Streeks, T. J., M. K. Owens, and S. G. Whisenant. 2005. Examining fire behavior in mesquite-acacia shrublands. International Journal of Wildland Fire 14:131140.

Thaxton, J. M., and W. J. Platt. 2006. Small-scale fuel variation alters fire intensity and shrub abundance in a pine savanna. Ecology 87:1331-1337.

Turner, M. G. 1989. Landscape ecology: the effect of pattern on process. Annual Review of Ecology and Systematics 20:171-197.

Van Wagner, C. E. 1973. Height of crown scorch in forest fires. Canadian Journal of Forest Research 3:373-378.

Wiedenfeld, C. C., And J. D. McAndrew. 1968. Soil survey of Sutton County, Texas. Washington, DC, USA: Soil Conservation Service, US Government Printing Office. $33 \mathrm{p}$.

Wiens, J. A. 1989. Spatial scaling in ecology. Functional Ecology 3:385-397.

Williams, J. E., R. J. Whelan, and A. M. Gill. 1994. Fire and heterogeneity in southern temperate forest ecosystems: implications for management. Australian Journal of Botany 42:125-137.

Williams, R. J., G. D. Сook, A. M. Gill, and P. H. R. Moore. 1999. Fire regime, fire intensity and tree survival in a tropical savanna in northern Australia. Australian Journal of Ecology 24:50-59.

Williams, R. J., A. M. Gill, And P. H. R. Moore. 1998. Seasonal changes in fire behaviour in a tropical savanna in northern Australia. International Journal of Wildland Fire 8:227-239. 